\title{
Evaluation and Engagement in Journalistic Commentary and News Reportage
}

\author{
Juana I. Marín Arrese and Begoña Núñez Perucha \\ Complutense University \\ juana@filol.ucm.es / begonia@filol.ucm.es
}

\begin{abstract}
This paper explores the expression of evaluation and the treatment of 'the same event' in news reportage and journalistic commentary in two languages (English, Spanish). In our analysis of the evaluative dimension, we draw on the framework of Appraisal Theory (Martin 2000; Martin and White 2005; White 2003, White 2004, inter alia), and elaborate on the analysis of the categories of evaluation, subsumed under the notion of Engagement, in relation to writer stance and to the dimension of subjectivity and intersubjectivity. The paper reveals the presence and patterning of the various linguistic resources for the expression of evaluation in these subgenres of journalistic discourse, and establishes comparisons across languages.
\end{abstract}

\section{Introduction}

Recent studies within the tradition of Register and Genre Theory (Eggins and Martin 1997), and studies of text types in the media (Ungerer 2000), have aimed to discover and make visible the relation between genres, as goal-oriented and situation-based groupings of texts, and the actual features of the language used in different types of texts (cf. Biber 1988). López García (1996: 232) refers to two main typologies of media texts identified by Vilarnovo and Sánchez (1992, chapter VII): (i) anglosaxon typologies, which make a distinction between stories (hard news and soft news) and comments (cf. Bell 1991); and (ii) latin typologies, which relate genre to attitude, giving rise to four types of media genres: reporting attitude (reportage), interpretive attitude (society pages), opinion attitude 
(opinion columns and leading articles), and finally, entertaining attitude (cartoon strips).

As regards the characteristics of the two major categories, report and comment (Bell 1991), news reports are placed in the front pages of the paper, and are typically constrained by temporal and content requirements, they report 'recent' past events and their aim is to present information which is newsworthy. López García (1996) places hard news within the category of informative use and describes them as characterised by impersonality and objective reference to information sources (dates, graphs, etc.). The purpose of news reports is purportedly the presentation of 'facts', as opposed to journalistic commentary, which deals with 'opinions' and assessments of those facts. This characterisation of news as showing low personal involvement of the authorial voice is in consonance with the expected, or 'presumed', objectivity of this type of genre (cf. Iedema, Feez and White 1994), in contrast with the higher degree of subjectivity present in explicitly evaluative texts. The category 'comment' is expressly signalled in the paper as the section which includes opinion material of various types, chief among them are opinion columns, which specify the name of the columnist, and leading articles or editorials, which are printed "under the paper's name and logo" and figure as "the paper's voice speaking direct to its readers (Verstergaard 2000: 155). This prototypical characterization of these genres fails to detect more indirect or covert means by which the writer positions him/herself with respect to the information proffered in news articles. As Fernández Parratt (1998) notes, reportage can be considered a 'multifaceted genre' in that it may incorporate some features of opinion subgenres. The fact that news reports make use of resources for the covert expression of subjective positioning has also been pointed out by studies on the production and reproduction of ideologies in media discourse (Fairclough 1995; van Dijk 2000).

This paper aims to explore the evaluative dimension in journalistic commentary and news reportage. We will be drawing on the framework of Appraisal Theory (Martin 2000; Martin and White 2005; White 2003, White 2004, inter alia), and more specifically on the resources of 'engagement', which include "all those locutions which provide the means for the authorial voice to position itself with respect to, and hence to 'engage' with, the other voices and alternative positions construed as being in play in the current communicative context" (Martin and White 2005: 94). Research in modality and evidentiality has shown that these linguistic resources are more frequent in journalistic commentary, but are nevertheless also present in news reportage (Hidalgo 2004; Marín-Arrese 2004; Marín et al. 2004). In this respect, as Martin and White (2005: 92) note, there is a tradition in discourse studies in which "all utterances are seen as in some way stanced or attitudinal".

It is hypothesized that journalistic commentary is characterized by the greater presence of the internal authorial voice, that is, by expressions of dialogistic positioning which convey the viewpoint of the writer towards the proposition, whereas news is characterized by the presence of expressions of attribution, whereby the writer acknowledges or distances $\mathrm{him} /$ herself from the viewpoints and assessments attributed to external voices.

Focussing on the expression of engagement in these genres, we address the above issues through the following objectives: 
(i) To make visible the presence and patterning of the various linguistic resources for the expression of Engagement in texts of journalistic commentary and news reportage; and

(iii) To establish comparisons of the patterning of these resources across these subgenres of newspaper discourse, and across languages.

This paper explores the treatment of 'the same event' in two texts of news reportage, unsigned 'hard' news and signed news reports, and two texts of journalistic commentary, leading articles and opinion columns respectively. The event described is Berlusconi's announcement of the withdrawal of Italian troops from Iraq, presumably linked to popular reaction in Italy at the shooting of $\mathrm{Mr}$. Calispari by American troops when he was taking part in the rescue of Ms Sgrena, a journalist who had been taken hostage in Iraq. The texts were chosen from two British quality newspapers representative of a different ideological slant (The Guardian, The Times):

Opinion column:

Leading article:

News report:

'Hard' news:
No escape from the war (The Guardian, 16-3-2005).

Italian reverse (The Times, 17-3-2005).

Italy to pull troops out of Iraq (The Times, 16-3-2005).

Italian troops to leave Iraq (The Guardian, 15-3-2005).

The paper also establishes a contrast with journalistic commentary and news reportage in Spanish. We analyze the following four texts:

Opinion column:

Leading article:

News report:

'Hard' news:
El eje del mal (E1 País, 17-3-2005).

Berlusconi e Irak (El País, 17-3-2005).

Italia anuncia que iniciará en septiembre una retirada parcial de sus soldados en Irak (ABC, 16-3-2005).

Berlusconi anuncia la retirada parcial de Irak (ABC, 16-3-2005).

Section 2 presents a general overview of the domain of Engagement. In section 3 we discuss the relation between Engagement, writer stance and (inter)subjectivity. Section 4 presents the results of our analysis, and the conclusions are offered in the final section.

\section{The domain of engagement}

\subsection{Evaluation and Engagement}

Within the framework of Appraisal Theory, Engagement accounts for those linguistic resources whereby the authorial voice positions itself with respect to other textual voices and alternative positions at stake in a given communicative context (Martin and White, 2005: 94). In other words, Engagement encompasses not only those evaluative uses of language by which speakers/writers (SP/WR) adopt a particular position or stance, but also 
those devices by which they interact with potential or real hearers/readers (HR/RD). In linguistic studies, all these resources have been traditionally considered under the headings of evidentiality, modality or hedging.

Engagement resources are characterised as dialogic in the sense that they are means by which the textual voice represents itself as acknowledging, engaging with, challenging or aligning itself with other utterances, which provide in some way alternatives to that being advanced by the text (White 2003: 260; White 2004).

Viewed in this way, Engagement is inscribed within a social dialogic perspective of communication, as proposed by Bakhtin (1981) and Voloshinov (1995). According to this perspective, all oral or written communication always takes up in some way previous utterances or anticipates future responses of real or imagined readers/listeners. When adopting particular positions and engaging with others, the speaker/writer can be said to enter into some form of potential negotiation with an ideal hearer/reader (cf. Fairclough, 1989: 49), who is positioned as sharing similar ideological viewpoints. For this reason, the analysis of intersubjective meanings involved in the domain of Engagement should also be connected with the rhetorical effects that this dialogistic positioning has on the overall function of discourse as social practice.

\subsubsection{The categories of Engagement within the Appraisal Theory Framework}

This section presents a general overview of the System of Engagement as described in Martin and White (2005) and points to some problems derived from the semantic scope assigned to some of the categories. The discussion will provide the basis for the proposal of our own categorisation of Engagement, which will be fully developed in section 3 .

Martin and White (2005) propose various subcategories within the domain of Engagement on the basis of a distinction between dialogic contraction and dialogic expansion. $^{2}$

\section{Dialogic contraction}

It accounts for those resources that aim to challenge or constrain the scope of dialogically alternative value positions and textual voices. Contractive meanings can be located into two categories: Disclaim and Proclaim.

The category Disclaim refers to meanings by which some alternative position is introduced in the text so as to be directly overruled, as in the case of dialogic denials (There is nothing wrong with it), or countered, as in expressions of counter-expectations (Admittedly, ..., but this action still).

The category Proclaim refers to overt formulations whereby the SP/WR shows agreement with the proposition, which is presented as reliable or valid. These expressions limit the scope of alternative positions and are arranged into three subcategories: (i) Concur, which includes, expressions which explicitly present the speaker/writer as sharing a particular view presented in the text (The action will, of course, benefit our country); (ii) Pronounce, or formulations which present the authorial voice as emphasising the value of 
his/her proposition or insisting on his/her warrantability (I contend that...); and, (iii) Endorse, which refers to expressions whereby the author presents attributed information as reliable and worth supporting (As research has shown / demonstrated....). ${ }^{3}$

\section{Dialogic expansion}

Dialogic expansion includes those expressions that open up the dialogic space for alternative positions and textual voices. Two main categories can be distinguished here: Entertain and Attribution.

First, the category Entertain refers to expressions by which the speaker/writer indicates that his/her position is one among different possible dialogic alternatives. This category includes a wide range of meanings, all accounting for the individual subjectivity of the authorial voice: (i) meanings of likelihood, conveyed by different types of expressions, from auxiliaries of epistemic modality and modal adjuncts to some mental verb attribute projections (it may rain tomorrow, perhaps he is just doing his job, I think, I believe, I'm convinced that...; (ii) meanings of evidence and appearance, whereby the proposition is presented as contingent and derived from the speaker's/writer's subjective attitude towards how he/she gained knowledge (It appears that...); (iii) expressions of deontic modality, such as those of permission and obligation (You must lock the door when you leave), and, finally (iv) expository questions or open ended rhetorical questions ${ }^{4}$.

Regarding Attribution, this category is concerned with the inclusion of other points of views by means of direct quotation or textual assimilations. This category includes verbs indicating communicative and mental processes (He says /thinks that....) as well as some expressions of "hearsay" (It is said that ...).

Martin and White (2005) distinguish two subcategories of Attribution: (i) Acknowledge, when the authorial voice does not specify its position with respect to the attributed material (He demanded... ; the Government says that...), and (ii) Distance, when he/she explicitly distances itself from the attributed information, thus taking no responsibility for its reliability (She has claimed that...).

As can be seen, in this dialogic view of Engagement, the distinction between intravocalisation and extra-vocalisation, and hence, the notion of intertextuality, seems to be secondary. In our opinion, this distinction is relevant to determining the Speaker/Writer's degree of personal involvement and the subjective-intersubjective potential of his/her positioning. For this reason, our proposal for the categorisation of Engagement draws on White's (2004) distinction between Dialogistic Positioning and Intertextual Positioning.

Dialogistic Positioning refers to how the SP/WR positions him/herself with respect to the anticipated reactions and responses of the addressee. On the other hand, Intertextual Positioning involves how SP/WR positions him/herself with respect to the attributed proposition, thus encompassing those linguistic resources by which speakers/writers quote or represent the words or viewpoints of other speakers/writers ${ }^{5}$. On this basis, the category of Attribution stands as the representation of Intertextual Positioning and, as such, accounts for all those cases of inclusion of external sources of information in the text. Thus, following White's (2004) the attributed information can be presented by the SP/WR in a 
neutral way (absence of endorsement) or in a biased way. In the last case the SP/WR can present the attributed utterances or beliefs as reliable and worth supporting (endorsement) or he/she can distance him/herself from them, thus taking no responsibility for its reliability (disendorsement).

From this remark, it follows that, in contrast to Intertextual Positioning, Dialogistic Positioning is mainly associated with instances of intra-vocalisation, or personal involvement of the SP/WR. Such a view is consistent with the evaluative component contained in the notion of writer stance and the possibility of having different degrees of subjectivity and intersubjectivity.

\section{Engagement, writer stance and inter/subjectivity}

In Marín and Núñez (2005), we revised White's (2004) categories, and elaborated on the analysis of the various subcategories of Engagement on the basis of the following notions (cf. Marín in press):

(a) The relation of the dialogic notion of engagement with the notion of SP/WR stance (Biber and Finegan 1989). According to Biber et al. (1999) involves three major domains: epistemic stance, attitudinal stance, and style. We believe that dialogistic positioning should include attitudinal stance, which involves the expression of assessments and value judgements as well as arguments regarding the necessity or desirability of the situation obtaining, as a distinct category from that of Entertain.

(b) The distinction within the semantic domain of Evidentiality of not only perceptual, but also cognitive and communicative modes of access to evidence (cf. Marin-Arrese 2004, in press). Evidentiality refers to the SP/WR's expressed attitudes towards knowledge, more specifically, to how they obtain and evaluate the validity of the information by appeal to the sources of evidence accessible to the SP/WR and to the hearer/reader (Mushin 2001; Plungian 2001, Marín-Arrese 2004 inter alia).

(c) The categories proposed by White (2004) relate to different degrees of subjectivity and intersubjectivity (Lyons 1977; Traugott 1995), so that we may observe a continuum from the expression of SP/WR's subjective evaluations, through potentially intersubjectively shared evaluations, to a shift in perspective to the subjective evaluations of some other textual voice. In this respect, Nuyts (2001) discusses the dimension of subjectivity vs. intersubjectivity as involving a distinction between the speaker's sole responsible for the epistemic evaluation of the state of affairs or, alternatively, whether the SP/WR shares this evaluation with others.

Bearing in mind these notions, we proposed the following subcategories of Engagement:

\section{A. Dialogistic positioning}

(i) Restricted engaged stance: These are statements by which the textual voice contracts the 
possibility of engaging in dialogistic positioning. This category is s restricted version of Martin and White's (2005) category of Dialogic contraction. We distinguish two main subtypes.

(a) Proclaim: Proclaim includes explicit expressions of personal involvement of textual voice, which restrict but allow for dialogic relations with the reader (I would argue that ...). These expressions underscore the highly subjective basis of the communicated information. Also included in this category are modally zero marked bare assertions, excluding dialogic relations with the reader, and presenting the information as 'factual', and therefore as maximally objective, as in:

(1) a. The Iraq war is a huge crime ... (Guardian, 16-3-2005).

b. Hay, por tanto, un resquicio de esperanza (El País, 17-3-2005).

(b) Disclaim: This category includes both dialogic denials as well as the expression of counter expectations. This includes negative assertions, expressions of concession, adversatives, and others. The rhetorical effect of the use of negation is the activation of its opposite positive information. Similarly, in concessions, some expected or presupposed position is countered by an alternative position.

(2) a. ...it might be tempting... . But experience suggests... (Guardian, 16-3-2005).

b. ... el ejército estadounidense no ha informado del incidente. (ABC, 16-3-2005).

(ii) Attitudinal stance: The textual voice engages in dialogistic positioning by appeals to the audience to conform with her/his views and expectations, thus attempting to persuade the audience via statements of value judgements or by expressing his/her wishes.

(a) Enforcement: Within this category, we have included expressions of deontic and dynamic modality (We must demand, We cannot accept...), which implicitly evoke the speaker/writer and which may also affect the hearer/reader intersubjectively. In this way the writer appeals to the readership to conform with her/his views and expectations.

(3) a. Second, we must demand that the occupation is brought to a speedy end (The Guardian, 16-3-2005).

b. Debe reconocerse, en todo caso, que... (El País, 17-3-2005).

(b) Affect: We include here affective processes (I hope ...), which explicitly designate the SP/WR's expectations and/or desires. Also included are expressions of volitional modality, expressing SP/WR's wishes and intentions.

(4) a. One must hope that... (Guardian, 16-3-2005).

b. Uno quisiera equivocarse... (El País, 17-3-2005). 
(iii) Epistemological stance: This category includes both explicit and implicit expressions whereby the textual voice manifests his/her estimations regarding the likelihood of the truth of the proposition, the perceptual evidence s/he appeals to, his/her mental attitude, or the hearsay evidence the textual voice has regarding the validity of the proposition.

(a) Likelihood: This subcategory includes epistemic modal expressions, which implicitly invoke the speaker/writer as sole conceptualizer and evaluator.

(5) a. ...The pressure to leave ... may, for most countries, become irresistible. (The Times, $17-$ 3-2005).

b. Their withdrawal is bound to increase pressure ... (The Times, 16-3-2005).

(6) a. El anuncio del primer ministro italiano puede tener también... (ABC, 16-3-2005).

b. Todo ello sin duda puede servir... (El País, 17-3-2005).

(b) Perception: Perceptual evidentials may refer to visual or other sensory sources of evidence experienced by the speaker. Evidentials may either explicitly or implicitly designate the speaker/writer as conceptualizer (subjectivity), and may also indicate that her/his evaluation may potentially be shared by the hearer/reader (intersubjectivity). In either case, the qualification is open to dialogic relations with the HR/RD.

(7) a. ...this administration is never so dangerous as when it sounds most absurd... (Guardian, 16-3-2005).

b. hoy parece imponerse ... (El País, 17-3-2005).

(c) Cognition: Cognitive evidential expressions include mental state verbs, which explicitly designate the speaker, and may also include the audience. Also included are indirect conclusional processes, and instances of metaphorical shift from the perceptual domain to the cognitive domain (i.e. KNOWING IS SEEING) (Lakoff and Turner 1989).

(8) a. ... and we must assume they will try to attain as many as possible, (Guardian, 16-32005).

b. Hoy sabemos que... (El País, 17-3-2005).

(d) Communication: This includes information to which the speaker has had direct access via communication (I hear that...), performative statements by the speaker, or cases of self-attribution. Also included in this category are metaphorical shifts involving verbs of communication to refer to cognitive conclusional processes.

(9) a. Los que hemos criticado ... (El País, 17-3-2005).

b. ... y quien esto escribe no tiene inconveniente en reconocerlo. (E1 País, 17-3-2005). 
(10) a. But experience suggests... (The Guardian, 16-3-2005).

b. La intrepidez ... sugiere que ...(El País, 17-3-2005).

\section{B. Attribution}

Following White (2004), this category includes the presentation of speech and thought, and represents a shift in viewpoint to that of some text external voice. The attributed proposition may be presented according to the different degrees of integration into the text (i.e., the communicated information of the textual voice): insertion vs. assimilation.

- Insertion: The textual voice uses direct speech, which purportedly presents the words of the external voice, the attributed source, by separating them from the text.

- Assimilation: There may be varying degrees of assimilation; in the use of indirect speech the words of the attributed source are assimilated in the text in such a way that the distinction between the voices has been blurred. There may also be a combination of both direct and indirect speech within the same sentence so that the external voice is partly inserted and partly assimilated with the textual voice.

As White (2003: 273) notes, "such formulations are retrospectively dialogic in that they represent the textual voice as referencing the utterances of prior communicative participants". The attributed material may be endorsed or dis-endorsed by the SP/WR, or alternatively the SP/WR may adopt a neutral position of non-committal or nonendorsement.

(i) Endorsement: This category includes cases where the textual voice "indicates that it stands with the attributed source in advancing the current proposition" (White 2003: 270). Such formulations thus involve intersubjectivity of the current textual voice and that of some other textual voice.

(11) a. The anti-war movement has spoken the truth on behalf of millions of citizens... (Guardian, 16-3-2005).

b. The coalition has..., correctly judging that... (The Times, 17-3-2005).

(ii) Dis-endorsement: The textual voice explicitly disowns the current proposition. At times, we may find more covert means of positioning, which we might term contextual disendorsement where the writer juxtaposes two contrasting attributions, as in (12b).

(12) a. To suggest it is somehow unreasonable... (The Guardian, 16-3-2005).

b. The US troops said the car had been speeding towards the checkpoint; Ms Sgrena and the car's driver denied this. (The Guardian, 16-3-2005).

(iii) Non-endorsement: The textual voice adopts a neutral position. There is no subjective involvement of the SP/WR. The external voices may be implicit, as in (14b). 
(13) a. Bowing to popular pressure, the Italian Government said last night that ... (The Times, 16-3-2005).

b. The Left was clearly hoping that... (The Times, 17-3-2005).

(14) a. El jefe de gobierno no indicó..., pero subrayó que...(ABC, 16-3-2005).

b. Se ha dicho repetidamente ... (El País, 17-3-2005).

\section{Engagement in journalistic commentary and news reports}

\subsection{Engagement in Journalistic Commentary vs. News Reports in English}

In our study, the opinion column from The Guardian shows features of all the categories of engagement. Particularly relevant are the instances of expressions which reflect the writer's concern with the issue of truth (Restricted engaged stance). Another recurrent feature is the use of expressions of attitudinal stance, reflecting authorial voice assuming the role of moral authority, and also involving the reader in the evaluation expressed.

In the category of epistemological stance, showing writer's subjective involvement in the information proffered, the most frequent features are those of judgements of likelihood and appeal to evidence, which makes reference to information presented as potentially also accessible to the reader (intersubjectivity).

Opinion columns also present examples of Attribution, though they show fewer cases of an external textual voice. Also significant is the fact that the external voice is rarely a specific, identifiable participant (George Bush), but rather some unidentified entity or some grouping (The front benches of both main parties, Some, $A$ correspondent to this paper from South Shields, those who marched, The anti-war movement). See table 1.

In our leading article from The Times, we observe the same general tendencies described above for opinion columns, but in far fewer instances. However, the amount of expressions of attribution is relatively higher than in the opinion column, thus sharing to some extent the characteristic engagement patterns found in news reports. Similarly, the external voices are typically specific, identifiable participants (Berlusconi, Tony Blair) as well as institutions and groupings (coalition leaders, The White House, The Left, Britain, America and Australia). See table 2.

Our analysis of news reports has shown that there is a lack of bare assertions expressing the author's positive or negative strong views (proclamations or disclaimers) on a particular subject, and no expressions of attitudinal stance. We found very few occurrences of expressions showing writer's epistemic stance. See tables 3 and 4 .

In this subgenre, the use of attribution, the introduction of external voices in the text, is the most common dialogistic strategy, in particular the expression of non-endorsement. The writer thus distances him/herself from the information presented, which contributes to provide a veneer of objectivity to the text, as the information conveyed is not the direct responsibility of the writer. The external voices are typically specific, identifiable participants (Signor Berlusconi) as well as institutions and groupings with high status 


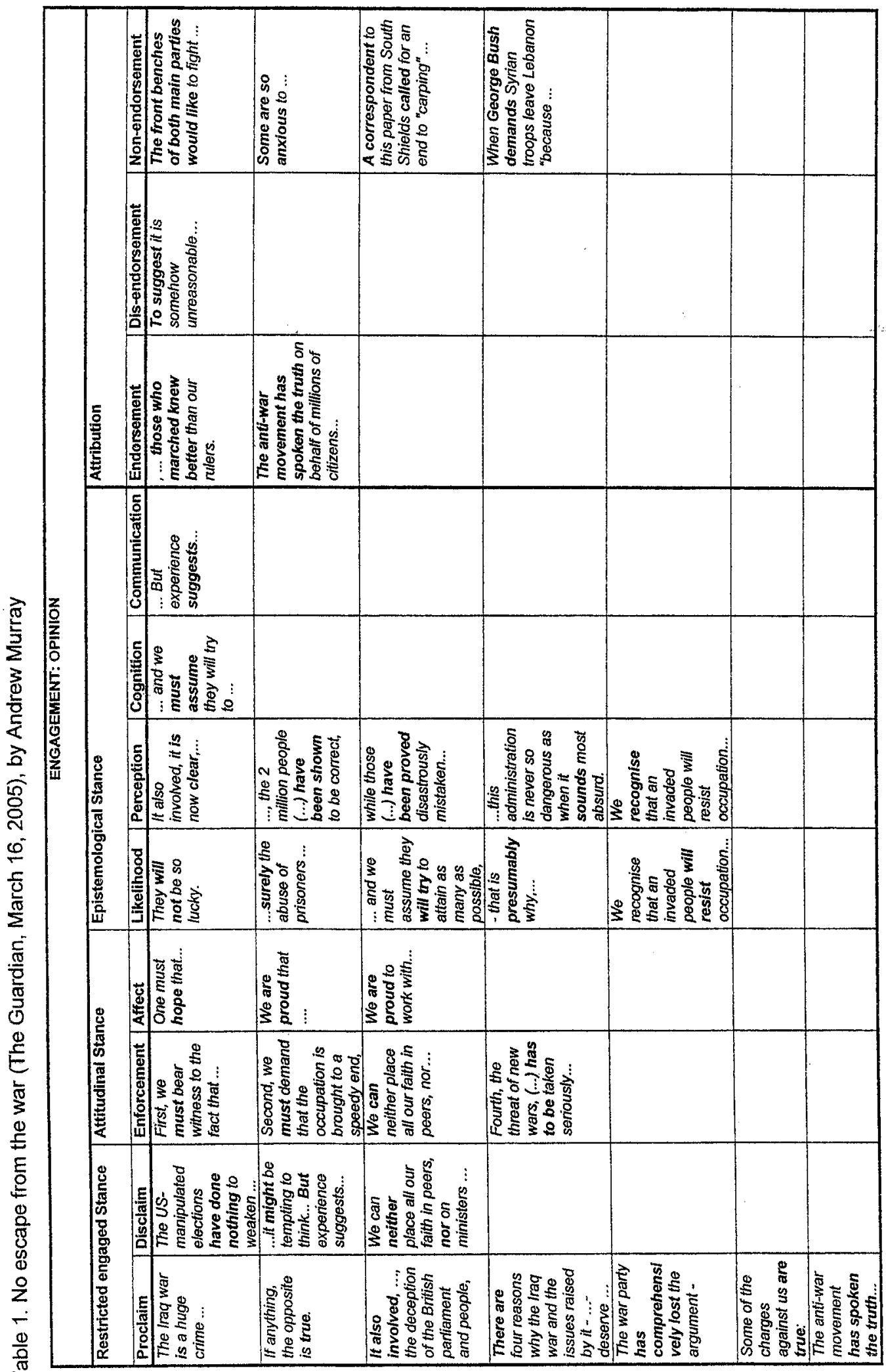




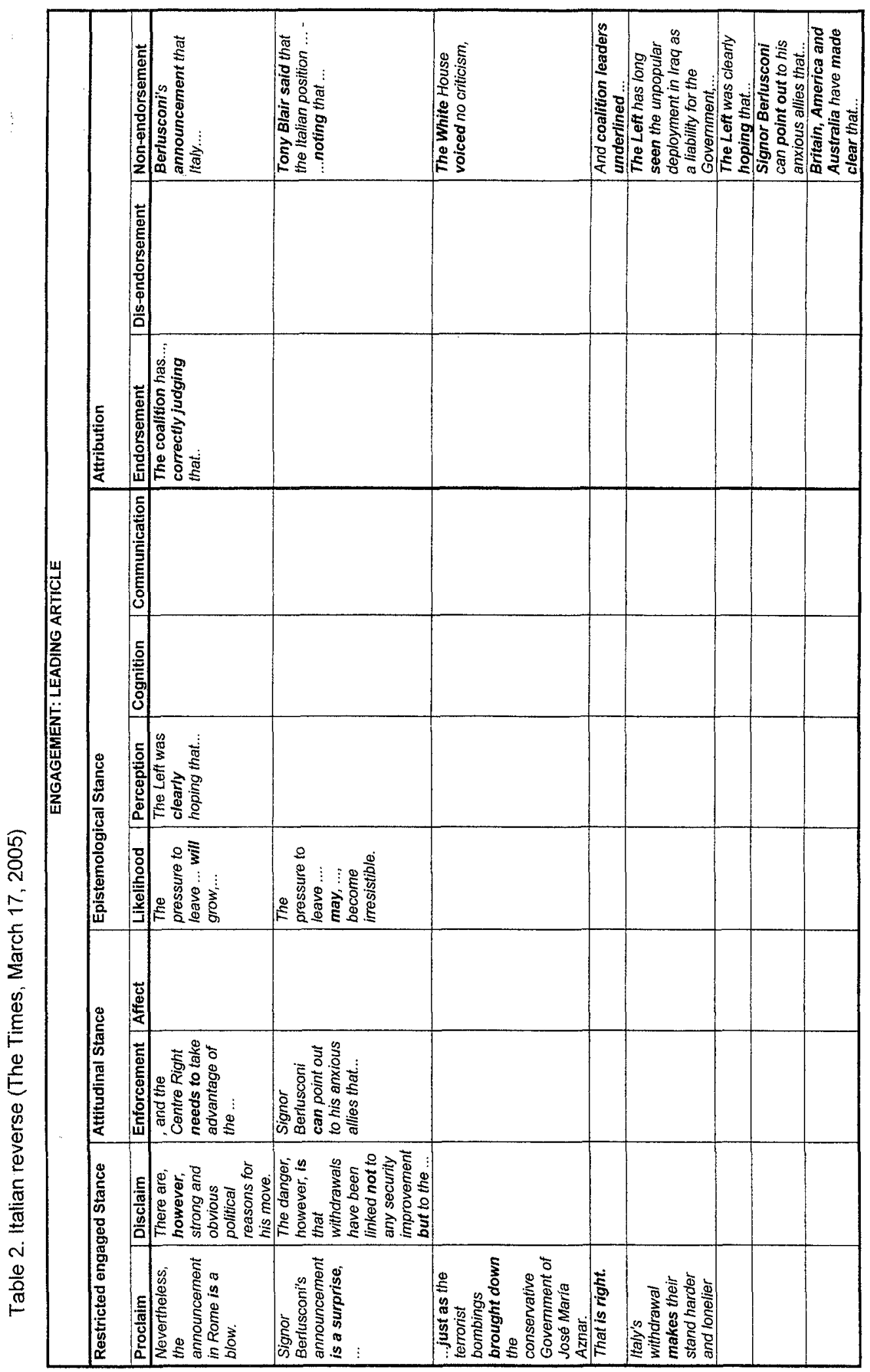




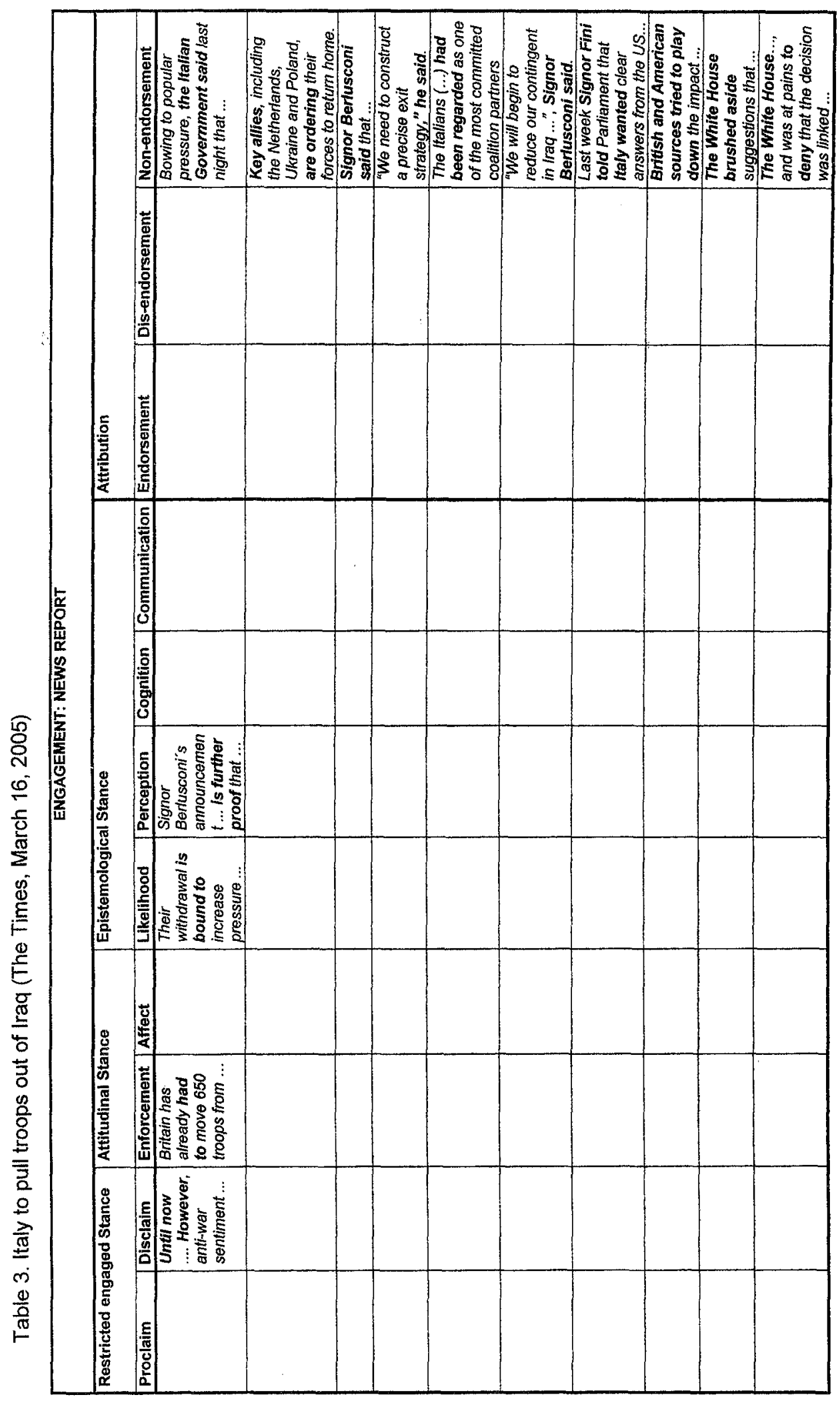




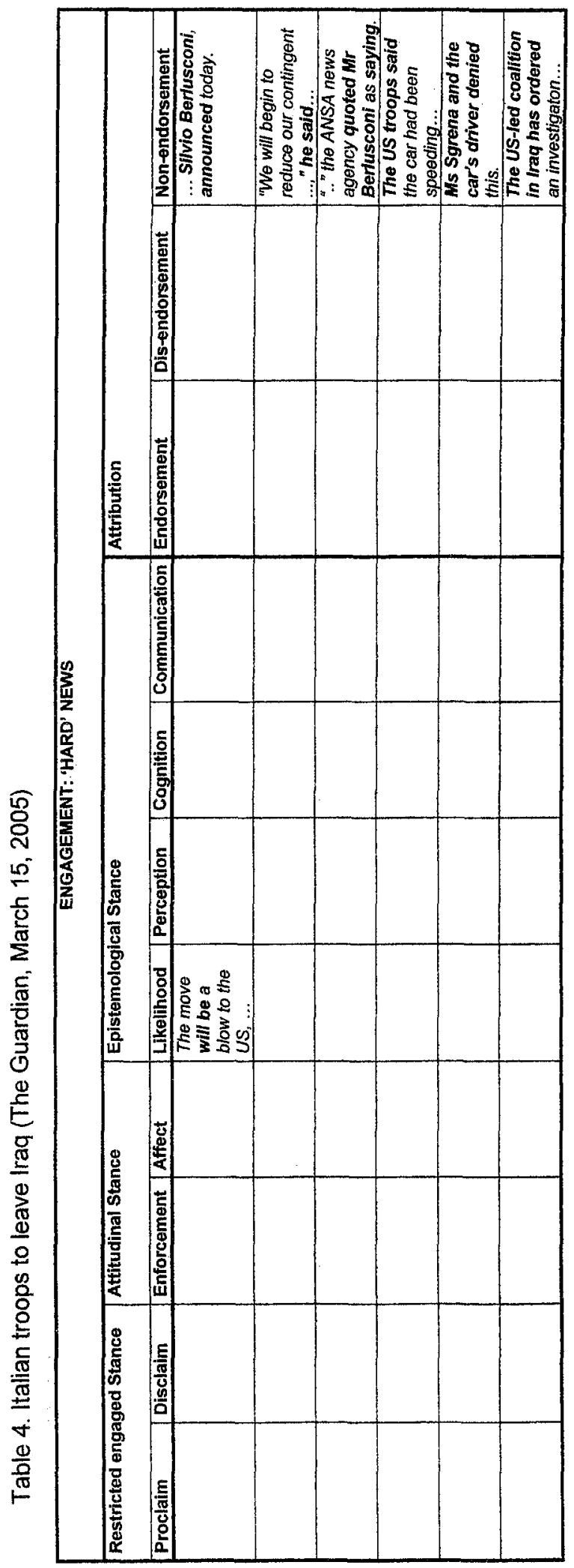


and/or power (British and American sources, The White House), and who would thus be perceived as reliable and/or expert sources of information.

As regards the comparison between the two newspapers in the insertion of other textual voices, Berlusconi and George Bush are the only text external voices whose words are inserted. In the case of assimilation, or representation by means of indirect speech, The Guardian introduces more external sources of information in both texts (The US troops, Ms Sgrena and the car's driver. The US-led coalition in Iraq. The anti-war movement), offering opposing views. In the texts from The Times we also find other external sources apart from Berlusconi, but these are all voices expressing the views of the coalition (Tony Blair, The coalition, Britain, America and Australia, Signor Fini, The White House, the Italian Government, British and American sources), except for one instance (The Left), whereby the writer places any opposition to the Iraq war within a particular 'nonprestigious' political stance. See table 5

\subsection{Engagement in Journalistic Commentary vs. News Reports in Spanish}

The two examples of journalistic commentary taken from El País reveal striking differences as to the way the writer shares his/her evaluative position with the reader. See tables 6 and 7.

At first glance, the comparison of both tables shows that the opinion column contains instances of almost all possible categories of Engagement and shows a high degree of writer's involvement. The pervasive presence of engagement resources in the text can be said to fulfil the following aims:

First, at a general level, these resources make evident the writer's stance regarding the information contained in the text by means of personal addresses to himself in examples showing instances of Restricted engaged stance (En mi opinión (todas las explicaciones) son ciertas menos la primera....), Attitudinal Stance (Los que hemos criticado (. . .) debemos reconocer) and Epistemological Stance (y quien esto escribe no tiene inconveniente en reconocerlo...; Todo esto explica, a mi modo de ver..). These personai references, which are missing in the leading article, are especially noticeable within the epistemological categories of Cognition and Communication.

As can be seen from the example illustrating attitudinal stance, it is possible to find co-occurrence of markers of attitudinal and epistemic stance in the same linguistic context. What is more, by using the inclusive pronoun "we" the writer does not only open up dialogic space but also aligns the reader into a particular view: Los que hemos criticado (Communication) $+(\ldots)$ debemos (Enforcement) + reconocer (Cognition).

Within the category of Likelihood, the opinion column text contains several expressions showing maximum degree of certainty in terms of writer's commitment towards the truth of the propositions expressed ("sin $d u d a$ "), which contribute to present the writer as a credible source of knowledge. In this sense, it contrasts with the more tentative examples found in the leading article (e.g. "lo probable").

Second, at a specific level, the use of questions in the opinion column illustrates how 


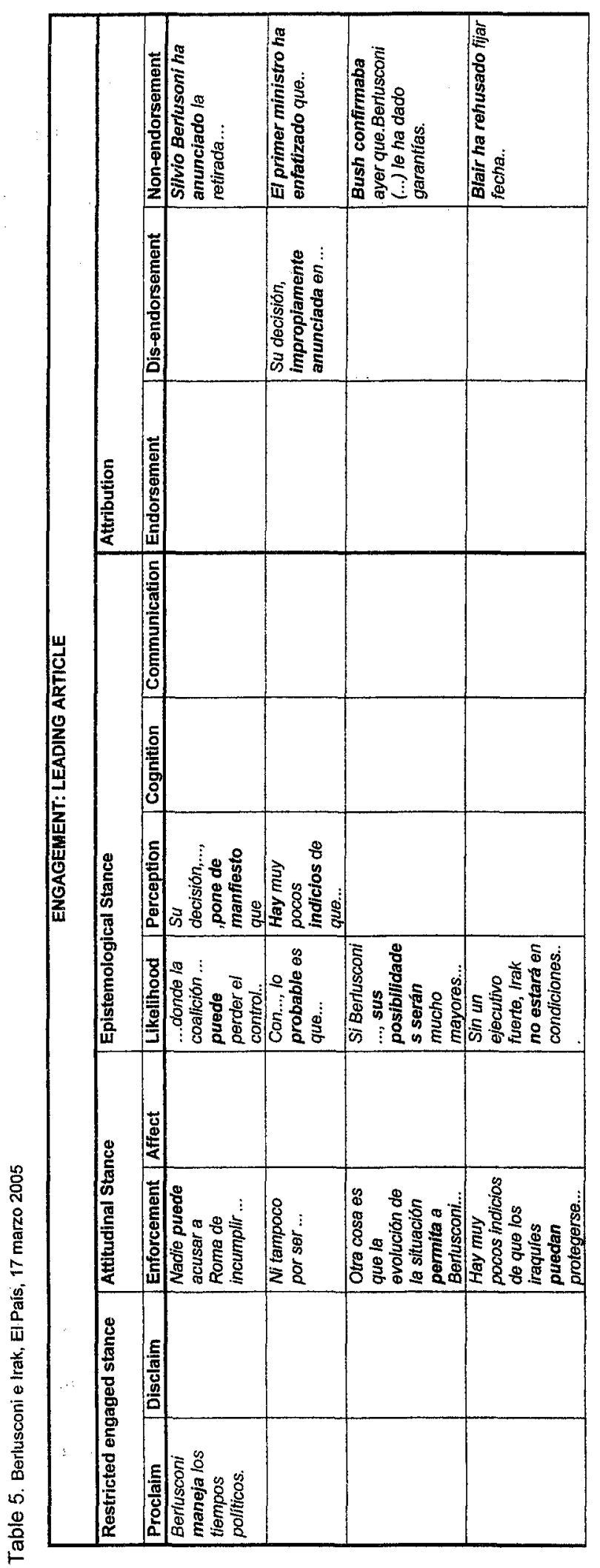




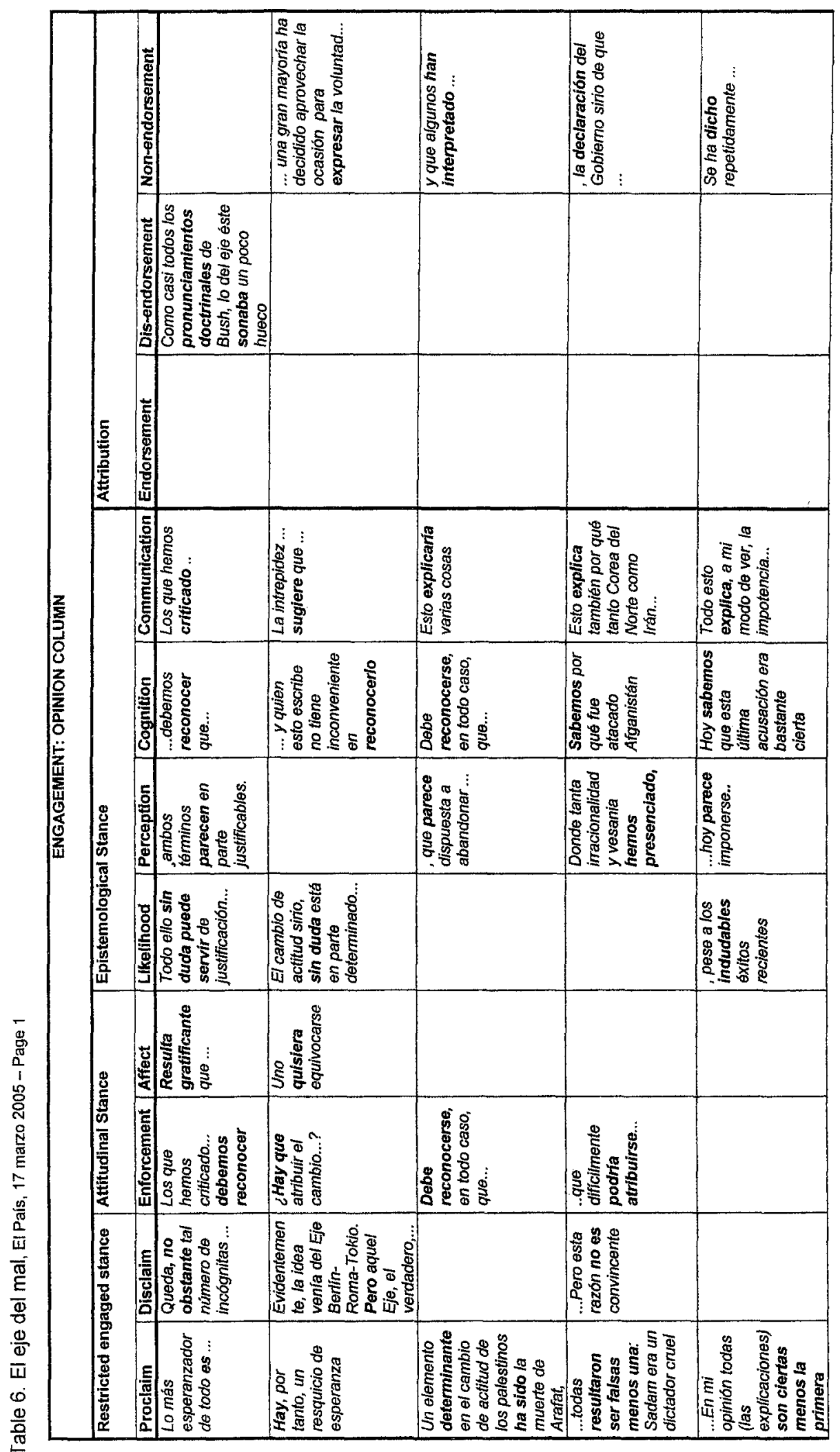




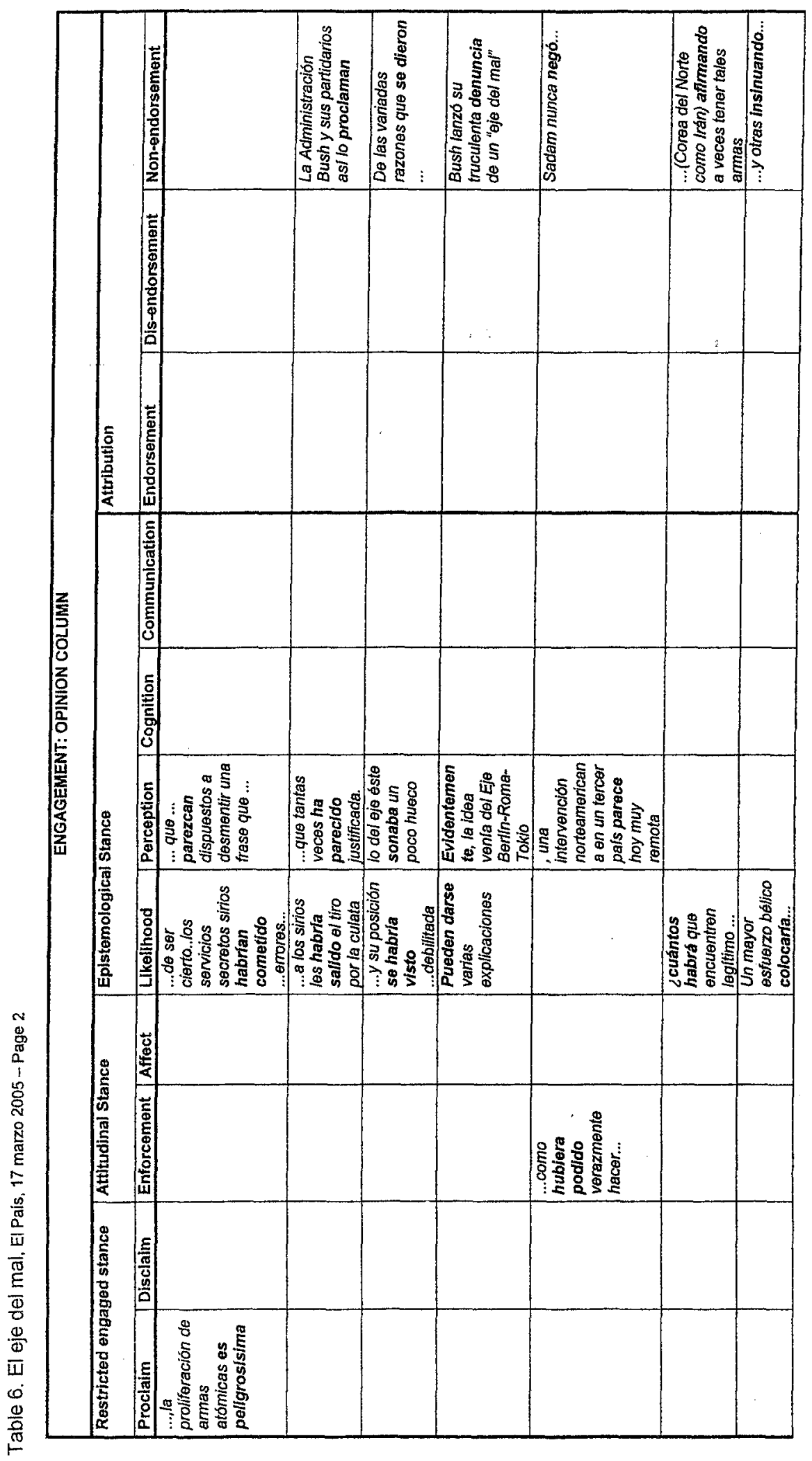




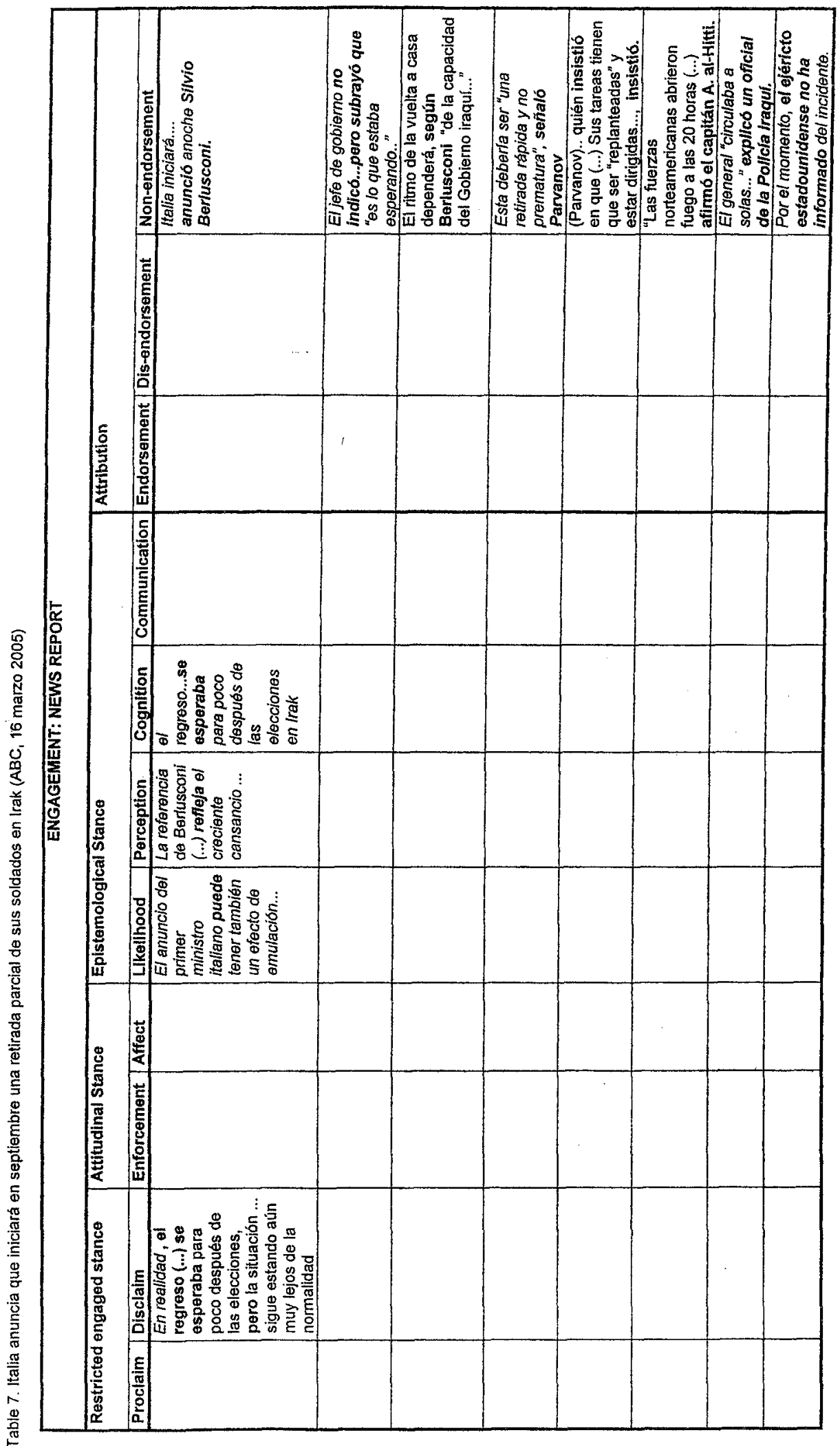


the writer manages his evaluative positions in a dialogue with the reader ( $i$ Hay que atribuir el cambio....?, ¿cuántos habrá...?)

In comparison to the leading article, the opinion column exhibits not only a maximum degree of subjectivity, but also a higher degree of intersubjective management and overt reader's involvement.

The hard news text and the news report, both from $A B C$, show a higher number of expressions of Attribution. Among the different modes of Attribution, the writer selects the neutral one. By doing so, he introduces external voices in the text, but does not show either alignment or disalignment with respect to the attributed information. See tables 8 and 9 .

However, in spite of the fact that both hard news and news report operate under objective regulations, as expected in these subgenres, there are differences regarding the number of external voices introduced in the texts and the extent to which these sources maximise the space for alternative views and align the reader into a given value position.

In the hard news text, all the external voices represent Italian authorities reporting on the withdrawal of the Italian troops (Berlusconi, the Ministry of Defence and a press release). There are no alternative views opening up for different alignments. In contrast, in the news report text, the inclusion of different sources of information (Berlusconi, Pavanov - the president of Bulgary, Captain Amin al Hitti, an Iraqui policeman and the US army) seems to place the reader against a polyphonic background involving two different issues: Berlusconi's decision of withdrawing the troops and the lack of security in Iraq.

Regarding writer stance, there are few expressions of writer's involvement in both types of news subgenres in comparison with the leading article and the opinion column texts. When comparing the news report text and the hard news text, both present one instance of Cognition and only the news report text shows instances of categories of Disclaim, Likelihood and Perception. In this regard, it should be noted that whereas the first part of the proposition illustrating Disclaim (D1) is related to the expression of counter-expectation as to the time the withdrawal of the Italian troops was expected, the second part of the Disclaim (D2) is consistent with the inclusion of voices of participants who have witnessed the atmosphere of violence in Irak, as has been previously mentioned: En realidad el regreso se esperaba para poco después de las elecciones (D1), pero la situación ... sigue estando aún muy lejos de la normalidad (D2.)

As a result, although the hard news text and the news report contain a higher number of instances of Attribution, the fact that the latter shows a higher number of external sources and a relatively higher number of examples within the categories of Restricted engaged stance and Epistemological Stance seems to allow for intersubjectivity and reader's involvement. Thus, the news report text can be said to show a higher degree of dialogic expansion in the sense that it allows for some dialogic engagement with the reader and makes visible alternative views. 


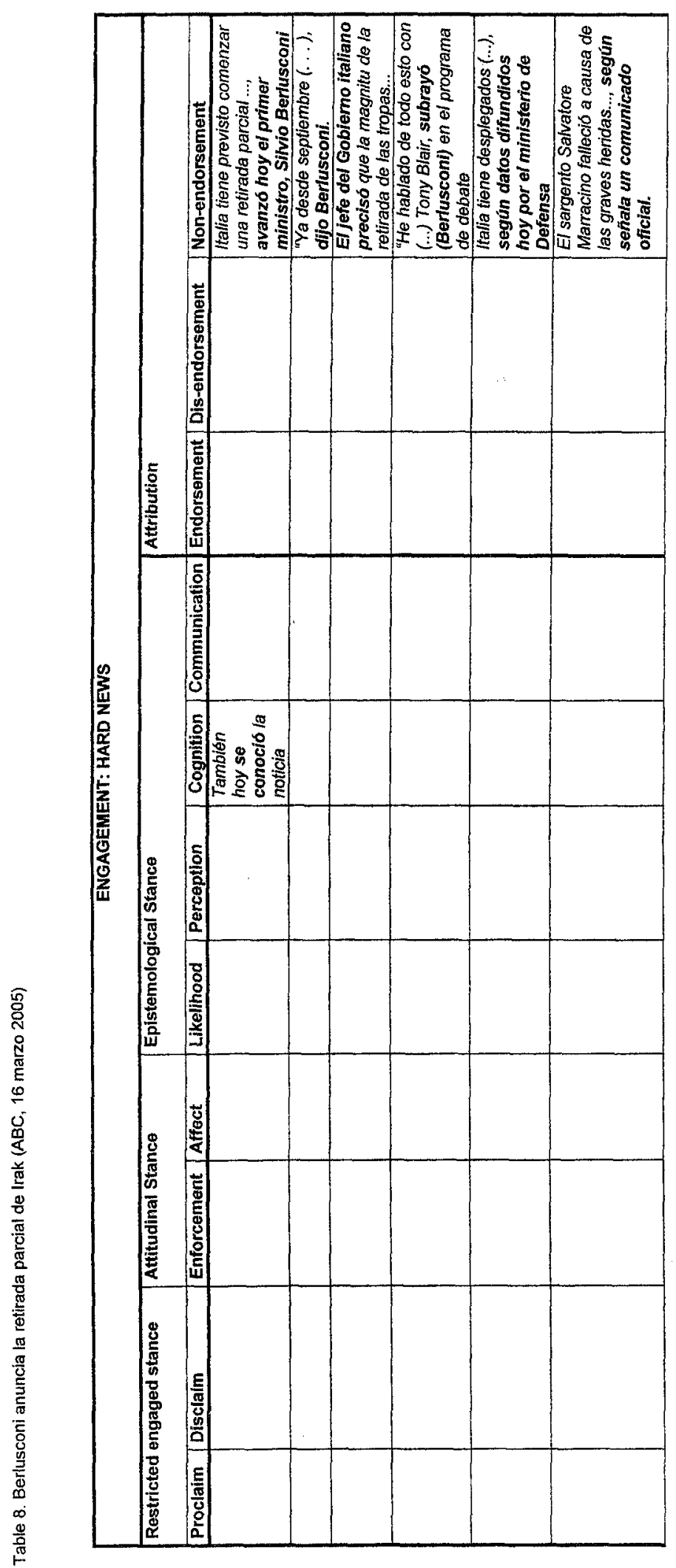




\section{Conclusions}

This paper has explored the engagement patterns in journalistic commentary and news reports. In our analysis, we have applied a refined version (cf. Marín and Núñez 2005) of White's (2003) categories of engagement, in terms of a continuum ranging from maximal subjectivity of writer voice, both explicitly and implicitly conveyed, through intersubjectivity, and finally to the expression of the perspective of some external voice.

As regards the comparison of the patterning of linguistic resources of engagement in the four subgenres, results indicate that whereas journalistic commentary clearly represents writer's subjective evaluations as well as writer-reader intersubjective views, news tends to rely on external voices as sources of authority and knowledge. Leading articles would appear to occupy some intermediate position; though close to opinion articles in the expression of writer's subjective evaluations, they also rely to a greater extent than the former on attribution of information to some external voice. 'Hard' news would represent the extreme position with practically a total lack of expressions of dialogistic positioning. The texts analysed thus conform to the expected prototypical features of these subgenres.

With regard to the distribution of Engagement resources across languages, the news texts share the same characteristics in both languages. The main differences are found in journalistic commentary. Opinion columns in Spanish tend to show a greater use of cognitive and communicative evidential expressions. As far as leading articles are concerned, there are differences regarding the linguistic resources of Dialogistic Positioning. Whereas the leading article from The Times shows a higher number of instances of Restricted engaged stance, especially examples of the category of Proclaim, the leading article from El País presents a higher number of expressions of both attitudinal and epistemological stance, thus exhibiting a higher degree of intersubjectivity and a slightly more cautious style, as indicated by the relatively higher amount of epistemic markers. These differences may, perhaps, be attributed to different ideological positionings in these particular texts. However, if this tendency is confirmed by further research regardless of the type of newspaper, it may point to cultural differences in the patterning and exploitation of Engagement resources in this subgenre.

\section{Notes}

1. This paper presents results of research funded by the Comunidad de Madrid (Research project: La variación lingüística en géneros y ámbitos discursivos en inglés y en castellano. Ref.: 06/HSE/0272/2004).

2. It should be noted that in Martin and White (2005) this distinction is based on the intersubjective potential of utterances rather than on the speaker's /writer's positioning as reacting to possible responses to the information presented (dialogistic positioning) or as acknowledging or evaluating words or thoughts from external sources (intertextual positioning). Cf. White (2004).

3. At the end of this section arguments will be provided in favour of the inclusion of Endorse within the category of Attribution, instead of Proclaim, following White (2004). 
4. White (2003: 267-268) observes that rhetorical questions can perform two types of dialogic function: a) present the proposition as one of a number of possible alternatives. This type has the communicative effect of dialogic expansion, as the question entertains different dialogic alternatives, and is the one included within the category of Entertain. b) Present the proposition as self-evident or 'common-sense', so that it is left up to the reader to supply the obvious answer. This type of questions closes down the space for dialogic alternatives (dialogic contraction).

5. As the author remarks, in the literature, those types of resources have been studied under the headings of 'attribution', 'direct and indirect speech', 'intertextuality' and even 'heteroglossia'.

\section{References}

Bakhtin, Mikhail M. (1981): The Dialogic Imagination (translated by C. Emerson and M Holquist). Austin: University of Texas.

Bell, Allan (1991): The Language of News Media. Oxford: Blackwell.

Biber, Douglas (1988): Variation across Speech and Writing. Cambridge: Cambridge University Press.

Biber, Douglas and Edward Finegan (1989): "Styles of Stance in English: Lexical and Grammatical Marking of Evidentiality and Affect". Text 1: 93-124.

Biber, Douglas, Stig Johansson, Geoffrey Leech, Susan Conrad and Edward Finegan (1999): Longman Grammar of Spoken and Written English. London: Longman.

Dijk, Teun A. van (2000): "New(s) Racism: A discourse analytical approach". In Simon Cottle, ed., Ethnic minorities and the media.. Buckingham, UK: Open University Press, 33-49.

Eggins, Suzanne and James R. Martin (1997): "Genres and registers of discourse". In T. van Dijk, ed., Discourse as Structure and Process. London: Sage, 230-256.

Fairclough, Norman. (1995). Media Discourse. London: Edward Arnold

Fernández Parrat, Sonia (1998): "El reportaje en prensa: un género periodístico con futuro. Revista Latina de Comunicación Social 4: 1-7.

[http://www.ull.es/publicaciones/latina/z8/r4absonia.htm].

Iedema, Rick, Susan Feez and Peter R. White (1994): Media Literacy. Sydney, Disadvantaged Schools Program, NSW Department of School Education.

Lakoff, George and Mark Turner (1989): More than Cool Reason. A Field Guide to Poetic Metaphor. Chicago: London: The University of Chicago Press.

López García, Ángel (1996): Escritura e información: la estructura del lenguaje periodístico. Madrid: Catedra.

Lyons, John (1977): Semantics, Vol. 2. Cambridge: Cambridge University Press.

Marín Arrese, Juana (2004): "Evidential and epistemic qualifications in the discourse of fact and opinion: A comparable corpus study". In J. Marín Arrese, ed., Perspectives on Evidentiality and Modality. Madrid: Editorial Complutense, 153-184.

(in press): "Commitment and Subjectivity/Intersubjectivity in Discourse". Volumen homenaje a Angela Downing. Madrid: Editorial Complutense.

Marín Arrese, Juana I., Laura Hidalgo and Silvia Molina (2004): "Evidential, epistemic and deontic modality in English and Spanish: The expression of writer stance in newspaper discourse". In R. Facchinetti and Frank Palmer, eds., English Modality in Perspective. Genre Analysis and Contrastive Studies. Frankfurt am Main: Peter Lang Verlag, 121-139. 
Marín Arrese, Juana and Begoña Núñez Perucha (2005): "Evaluation and Structuring in the Discourse of Fact and Opinion: A contrastive study". Paper presented at the Fourth International Contrastive Linguistics Conference, Universidad de Santiago, 19-23 septiembre 2005.

Martin, James R. and Peter White (2005): The Language of Evaluation. Appraisal in English. New York: Palgrave.

Mushin, Ilana (2001): Evidentiality and Epistemological Stance. Amsterdam: John Benjamins.

Nuyts, Jan (2001): Epistemic Modality, Language, and Conceptualization: A Cognitive-Pragmatic Perspective. Amsterdam: Benjamins.

Plungian, Vladimir (2001): "The place of evidentiality within the universal grammatical space". Journal of Pragmatics 33: 349-357.

Traugott, Elizabeth (1995): "Subjectification in grammaticalisation". In D. Stein and S. Wright, eds., Subjectivity and Subjectivisation: Linguistic Perspectives. Cambridge: Cambridge University Press, 31-54.

Ungerer, Friedrich (2000): "News stories and news events". In F. Ungerer, ed., English Media Texts Past and Present. Amstersdam: John Benjamins, 177- 195.

Vestergaard, Torben (2000): "From genre to sentence: The Leading Article and its linguistic realization". In F. Ungerer, ed., English Media Texts Past and Present. Amstersdam: John Benjamins, 151-173.

Vilarnovo, Antonio and José Francisco Sánchez (1992): Discurso, tipos de texto y comunicación. Pamplona: EUNSA.

Voloshinov, Valentin N. (1995): Marxism and the Philosohpy of Language, Bakhtinian Thought -an Introductory Reader. S. Dentith, L. Matejka and I.R. Titunik (trans.). London: Routledge.

White, Peter (2003): "Beyond modality and hedging: a dialogic view of the language of intersubjective stance". Text 23 (2): 259-284. . (2004): "An introductory course in Appraisal Analysis". Appraisal website: [http://www.grammatics.com/appraisal]. 